\title{
Influence of comorbidities on CD4+/CD8+ proportion in HIV-positive patients in Blumenau, State of Santa Catarina: a retrospective study
}

\author{
Keila Zaniboni Siqueira Batista ${ }^{[1]}$, Bárbara Bogoni ${ }^{[2]}$, Renata Cristina Müller ${ }^{[2],}$ \\ Camila Corrêa Penedo ${ }^{[3]}$ and Hercílio Higino da Silva Filho ${ }^{[1]}$
}

[1]. Laboratório de Imunologia, Departamento de Ciências Naturais, Universidade Regional de Blumenau, Blumenau, SC, Brasil. [2]. Departamento de Medicina, Centro de Ciências da Saúde, Universidade Regional de Blumenau, Blumenau, SC, Brasil. [3]. Programa de Residência Médica em Cirurgia Geral, Hospital Santa Isabel, Blumenau, SC, Brasil.

\begin{abstract}
Introduction: The objective was to identify comorbidities related to HIV-positive patients in Blumenau, State of Santa Catarina. Methods: A retrospective, descriptive observational design study which analyzed data from 424 patients assisted by the sexually transmitted disease/acquired immunodeficiency syndrome (STD/AIDS) Specialized Care Service (SCS). Results: Of 424 medical records analyzed, 388 patients presented $\mathrm{CD}^{+} / \mathrm{CD}^{+}$ratios lower than 1 . The most prevalent comorbidities were smoking, depression, alcoholism, and herpes zoster infection, in males and females. Conclusions: The most relevant comorbidity in both genders was herpes zoster, an important marker of immunity in patients. The lowest mean was observed among patients with neurotoxoplasmosis.
\end{abstract}

Keywords: HIV infection. Comorbidities. $\mathrm{CD} 4^{+} / \mathrm{CD} 8^{+}$ratio.

The major mediators of cellular immunity, T cells are divided into two main subtypes, the cluster of differentiation $4\left(\mathrm{CD} 4^{+}\right)$ helper and $\mathrm{CD} 8^{+}$cytotoxic $\mathrm{T}$ lymphocytes ${ }^{1}$. $\mathrm{CD} 4^{+} \mathrm{T}$ cells are selective targets of the human immunodeficiency virus (HIV), which can also infect macrophages and monocytes ${ }^{2,3}$. These leukocytes coordinate the cellular immune response against pathogens and participate in the activation of B lymphocytes (BL) and CD8+ T cells activation ${ }^{1}$.

The replication of the HIV results in the destruction of infected CD4+ T lymphocytes (cytopathic effect). In patients infected, there is a reduction in the number of $\mathrm{CD}^{+}$cells, a transient increase in the number of $\mathrm{CD}^{+}$cells, and consequently an inversion of the $\mathrm{CD}^{+} / \mathrm{CD}^{+}$ratio. During the progression of the infection, the number of $\mathrm{CD} 8^{+}$cells tends to increase while the number of $\mathrm{CD}^{+}$cells continues to decline ${ }^{4}$.

Therefore, the CD4+/CD8+ ratio, closely associated with HIV infection, reflects the degree of impairment of the immune system. Health individuals usually have a higher number of $\mathrm{CD}^{+}$than $\mathrm{CD} 8^{+}$cells, characterizing a ratio higher than $1^{5}$. Previous studies have demonstrated the relevance of the $\mathrm{CD}^{+}$/

Corresponding author: Dra. Keila Zaniboni Siqueira Batista.

e-mail: keila_siqueira@furb.br

Received 19 December 2016

Accepted 23 June 2017
$\mathrm{CD} 8^{+}$ratio in predicting the clinical progression of disease in HIV patients. A low $\mathrm{CD}^{+} / \mathrm{CD}^{+}$ratio is associated with an increased risk of disease progression, regardless of the $\mathrm{CD}^{+}$ cell count ${ }^{6}$. Furthermore, patients who normalize the ratio have a better prognosis and less-impaired immune system ${ }^{6}$.

Patients with HIV may have several comorbidities that could contribute to the reduction in the $\mathrm{CD} 4^{+} / \mathrm{CD}^{+}$ratio. It has been observed that long-term smoking decreases the number of $\mathrm{CD} 4^{+}$ cells, and increases the number of $\mathrm{CD} 8^{+}$cells ${ }^{7}$.

Our objective was to identify comorbidities related to HIVpositive patients treated at the sexually transmitted disease/ acquired immunodeficiency syndrome Specialized Care Services (STD/AIDS SCS) during the 2004-2009 period, in Blumenau, Santa Catarina. Also, this analysis was intended to show the influence of these comorbidities in the $\mathrm{CD} 4^{+} / \mathrm{CD} 8^{+}$ relation.

Of all 424 evaluated medical records that had data regarding $\mathrm{CD}^{+} / \mathrm{CD}^{+}$ratio, 388 patients presented values lower than 1 . The analysis by sex showed $41 \%$ female and $59 \%$ male patients. The mean age of these patients was $35.54( \pm 11.01)$ years, and the average age among HIV-positive men and women was 36.59 and 34.23 years, respectively. Of the 388 included patients, $243(62.6 \%)$ were using specific antiretroviral drugs for HIV infection, highly active antiretroviral therapy (HAART), while $145(37.4 \%)$ had never been on antiretroviral therapy $(n=113)$ or did not adhere to treatment $(n=32)$. 
The mean $\mathrm{CD}^{+} / \mathrm{CD} 8^{+}$ratio among the 388 patients was 0.387 . Among the patients taking antiretroviral drugs, the average ratio was 0.343 , and was higher among females $(0.440)$ than males $(0.264)$. Among those who were not on HAART, the average ratio was 0.461 , slightly higher in females $(0.477)$ than in males (0.453).

Among the patients with $\mathrm{CD} 4^{+} / \mathrm{CD} 8^{+}$ratio values lower than 1,33 different comorbidities were identified. Also, comorbidities were more often associated with these patients, and the most prevalent in descending order were: $96(32.1 \%)$ reports of smoking, $41(13.7 \%)$ of depression, 40 (13.3\%) cases of alcoholism, $36(12.1 \%)$ of herpes zoster infection, $30(10 \%)$ cases of illicit drug use, 21 (7\%) patients with neurotoxoplasmosis, $19(6.4 \%)$ patients with psychiatric diseases, and 16 (5.4\%) with hypertension. It is important to note that several individuals had more than one comorbidity. Moreover, some participants were not included because they had fewer incident comorbidities or did not have any of the associated comorbidities described $(\mathrm{n}=89)$.

The prevalence of major comorbidities was also analyzed according to gender category. As a result, differences were observed between genders regarding the main comorbidities (Figure 1). Among male patients, the most common comorbidities were smoking (33.3\%), alcoholism (16.7\%) and herpes zoster disorders (14\%). Among women, the three most prevalent comorbidities were smoking $(30.1 \%)$, depression (24.8\%) and herpes zoster infection (8.8\%).

It was also evident from the observation of the prevalence of comorbidities according to age (15-25, 26-35, 36-50, 51-60 and $>60$ ) that patients with ages between 36 and 50 years were most affected by comorbidities, representing more than half of the cases in women (56.6\%). Among men, although this age group was also the most affected, individuals with ages between 26 and 35 years were also strongly affected by comorbidities previously mentioned as prevalent.

In addition, we analyzed the average $\mathrm{CD} 4^{+} / \mathrm{CD} 8^{+}$ratio in each gender and the associated comorbidity. The lowest mean was observed among patients with neurotoxoplasmosis in both genders - men corresponding to 0.22 and women to 0.19 .

The variation in amplitudes of the $\mathrm{CD} 4^{+} / \mathrm{CD} 8^{+}$ratio was also calculated, and this was higher in male patients with depression [standard deviation $(\mathrm{SD})=0.2576$, values between 0.04 and $0.96]$ and female users of illicit drugs $(\mathrm{SD}=0.2835$, values between 0.23 and 0.98 ).

According to the Mann-Whitney $U$ test, it was evident that there was a significant difference between both genders in the mean $\mathrm{CD} 4^{+} / \mathrm{CD} 8^{+}$ratio in smokers and alcoholics (p-value $<0.05$ ). This data suggests that both comorbidities had more influence on males than females. Furthermore, using the Kruskal-Wallis test, significant differences were observed between the median $\mathrm{CD}^{+} / \mathrm{CD}^{+}$ratio in different comorbidities when we compared males and females separately (Figure 2).

The latest Brazilian Acquired Immunodeficiency Syndrome/ Sexually Transmitted Diseases (AIDS/STD) Epidemiological Bulletin revealed that the 20-29 year age group had the highest incidence of HIV infection ${ }^{8}$. In our study, there was a divergence of the data, since the disease was more prevalent in the 30-39 year age group.

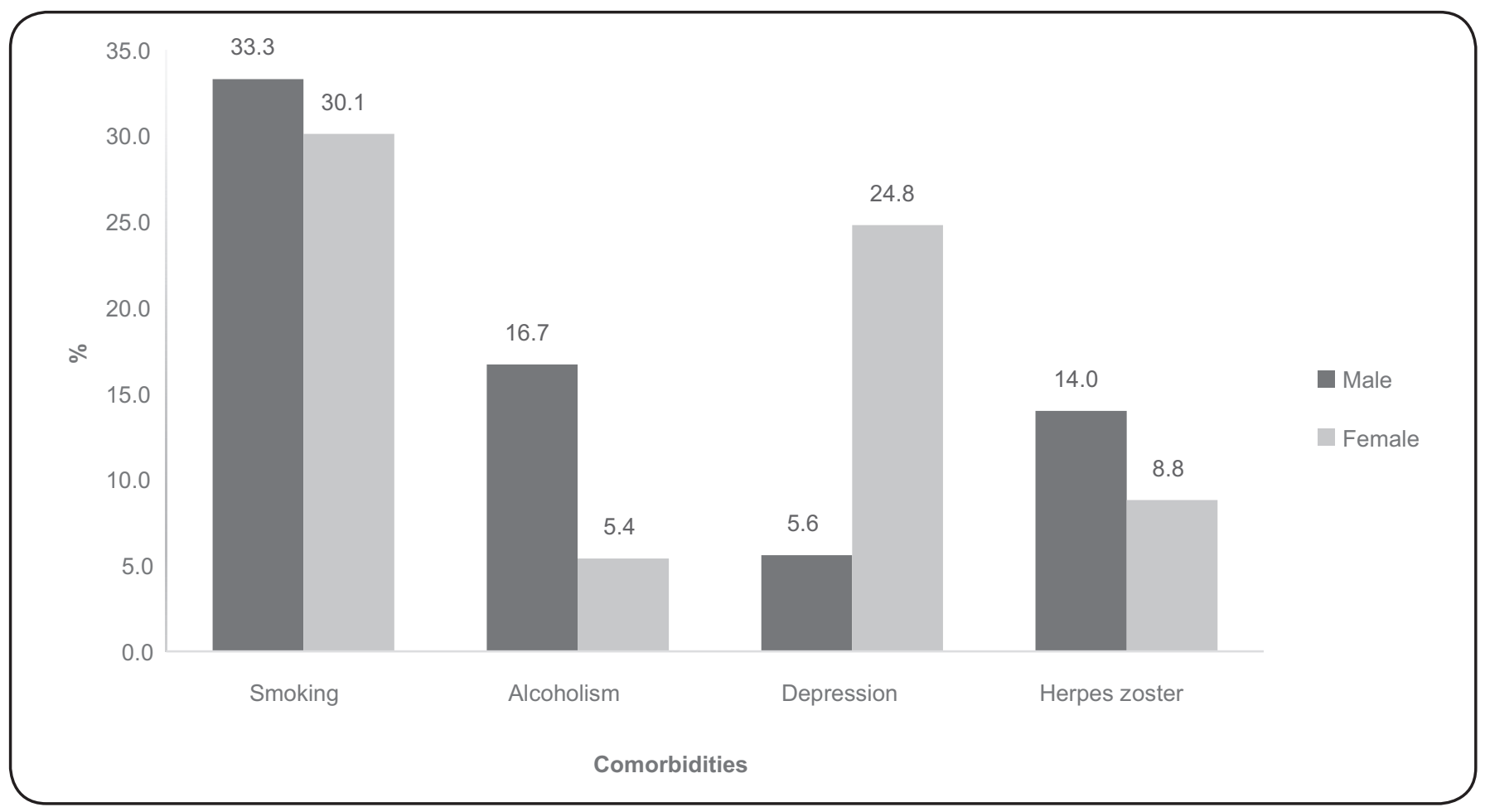

FIGURE 1 - Proportions of major comorbidities observed, per gender, in patients treated at the STD/AIDS SCS, Blumenau, SC, from January 2004 to December 2009. STD/AIDS SCS: sexually transmitted disease/acquired immunodeficiency syndrome Specialized Care Service. 


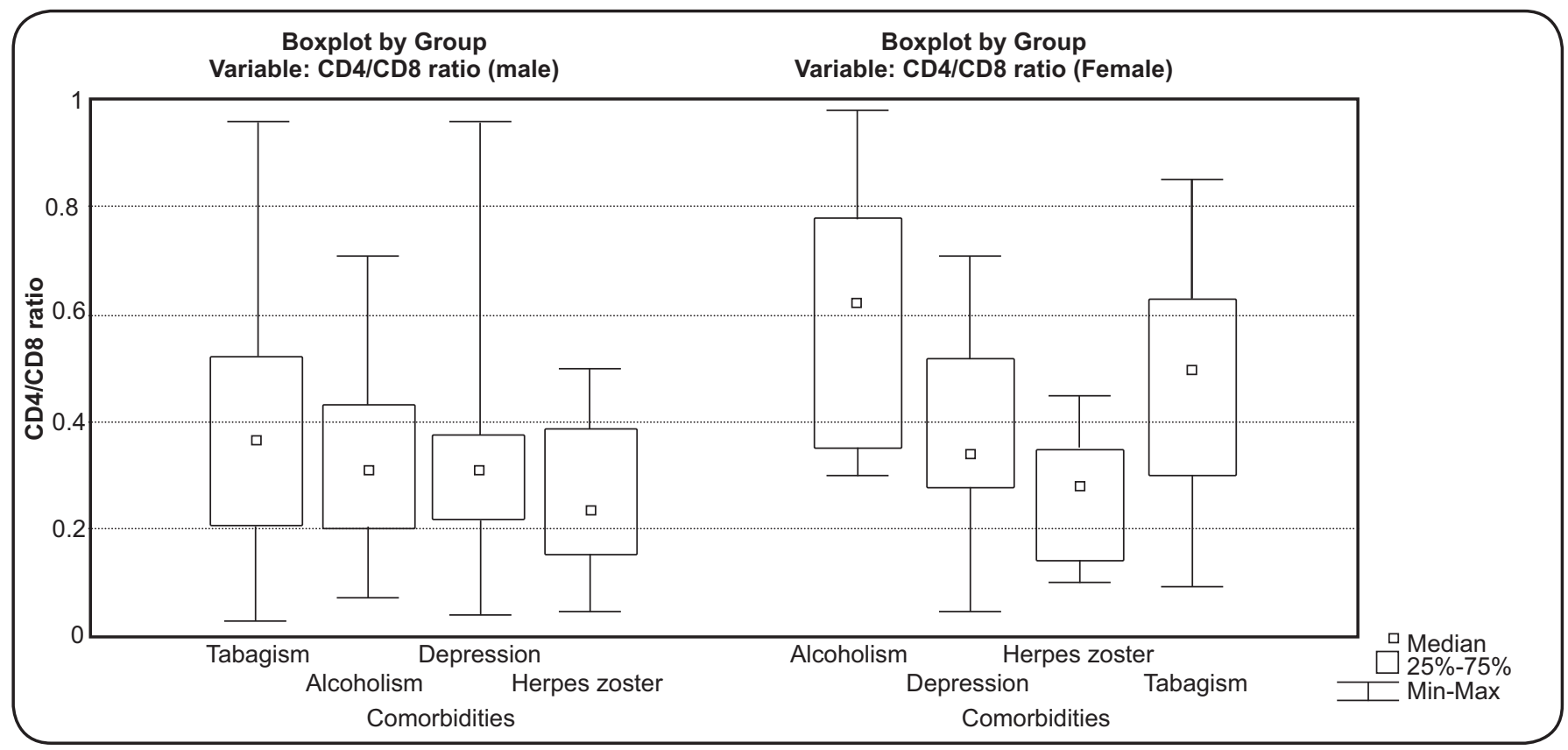

FIGURE 2 - Box plots showing $\mathrm{CD}^{+} / \mathrm{CD}^{+}$ratio by comorbidity, per gender, in patients treated at the STD/AIDS SCS, Blumenau, SC, from January 2004 to December 2009. CD4/CD8: T lymphocytes cluster of differentiation 4/cluster of differentiation 8; STD/AIDS SCS: sexually transmitted disease/ acquired immunodeficiency syndrome Specialized Care Service.

Regarding CD4+/CD8+ ratio, the proportion of individuals with values lower than 1 was higher among males $(59 \%$ of cases). The same pattern was reported by Guerro et al. ${ }^{9}$, who analyzed data from HIV patients admitted to hospital in Southern Brazil and found most to be male (67.4\%). Between 2007 and 2015, among all cases of HIV reported by the Notifiable Diseases Information System (SINAN), Department of Ministry of Health of Brazil, there was a total of 61,904 cases in men and 31,331 cases in women ${ }^{8}$.

In several studies, early antiretroviral therapy in HIVpositive patients has been associated with a rapid increase in the number of $\mathrm{CD} 4^{+}$cells and, therefore, $\mathrm{CD} 4^{+} / \mathrm{CD}^{+}$ratio $^{10}$. However, other studies suggest that $\mathrm{CD} 4^{+} / \mathrm{CD} 8^{+}$ratio tends to remain low in the first months of treatment, which could explain the lower mean ratio between patients on HAART in this study, and would be related to the greater number of complications related or unrelated to AIDS ${ }^{11}$.

Among males, significant differences $(p$-value $<0.05)$ in $\mathrm{CD}^{+} / \mathrm{CD}^{+}$ratio were found between tabagism and herpes zoster infection, depression, and alcoholism. Analyzing $\mathrm{CD}^{+} /$ $\mathrm{CD}^{+}$ratio values (Figure 2), we noticed that there was a significant variation in the main comorbidities analyzed in females, with a lower influence of alcoholism on the values of $\mathrm{CD}^{+} / \mathrm{CD}^{+}$ratio. This was not as obvious with respect to depression, the presence of herpes zoster infection, and smoking. In males, on the other hand, it was noted that all comorbidities influenced the low values of $\mathrm{CD} 4^{+} / \mathrm{CD} 8^{+}$ratio.

Smoking has been associated with an increased risk of developing AIDS and further progression of the disease, and an increased risk of developing tuberculosis in immunocompromised patients. Although there are no other studies comparing the
$\mathrm{CD}^{+} / \mathrm{CD}^{+}$ratios in smokers and nonsmokers among HIVpositive patients, it has been observed that heavy smoking ( $>50$ pack-years) can result in a decreased $\mathrm{CD}^{+}$cell count, and particularly, an increased $\mathrm{CD} 8^{+}$cell count, which could contribute to an increased susceptibility to several infections? Some studies have shown a reduction in $\mathrm{CD}^{+}$cell count in HIV-positive patients who were heavy alcohol consumers, which could have a negative effect on disease progression ${ }^{12}$.

According to the literature, parasitic and infectious diseases are the main causes of hospitalization among HIV-infected patients ${ }^{9}$. Neurotoxoplasmosis was the most prominent in this study, resulting in lower $\mathrm{CD} 4^{+} / \mathrm{CD} 8^{+}$ratios in both genders.

Herpes zoster, the third commonest disease in both men and women in the current study, is known to have higher incidence rates in HIV-infected patients (threefold) than the general population. After the institution of antiretroviral therapy (HAART), there was a marked decline in the risk of herpes zoster infection among HIV-infected patients ${ }^{13}$. In the present study, herpes zoster infection was a more relevant comorbidity in both genders, showing that it was an important marker of immunity in these patients. Blank et al. ${ }^{14}$ revealed that the incidence of herpes zoster infection remains a risk factor, especially in patients with low CD4 count.

The prevalence of depression in a validation study was estimated to be $10.5 \%$ from a total of 388 patients with $\mathrm{CD}^{+} /$ $\mathrm{CD} 8^{+}$ratio $\leq 1$. Huang et al. ${ }^{15}$ reported a lower number of $\mathrm{CD} 8^{+}$cells in depressed patients compared to patients without depression, in addition to an increase in the $\mathrm{CD} 4^{+} / \mathrm{CD} 8^{+}$ratio in patients treated with fluoxetine.

The lowest mean $\mathrm{CD}^{+} / \mathrm{CD}^{+}$ratio was observed among patients with neurotoxoplasmosis in both genders 
(men corresponding to 0.22 and women to 0.19 ). Further studies are necessary to assess the role of $\mathrm{CD} 4^{+} / \mathrm{CD} 8^{+}$ratio in determining disease progression, and also to understand the effect of comorbidities on the $\mathrm{CD} 4^{+} / \mathrm{CD} 8^{+}$ratio in HIV-infected patients.

\section{Ethical considerations}

This study was a retrospective, descriptive, and observational analysis of data from 424 patients assisted by the SCS, Blumenau/ SC, from January 2004 to December 2009. Variables such as CD4+/CD8+ ratio, age, gender, and their associations were analyzed. This study was approved by the Ethics Committee on Human Research of the Universidade Regional de Blumenau (FURB), under the protocol number 219/09.

\section{Acknowledgements}

Our utmost thanks and sincere gratitude go to the STD/AIDS Specialized Care Service (SCS) coordinator and his team.

\section{Conflict of interest}

There is no conflict of interest.

\section{Financial support}

Funded by the Graduate Medicine Program, Universidade Regional de Blumenau (FURB).

\section{REFERENCES}

1. Abbas AK, Lichtman AH, Pillai S. Cellular and Molecular Immunology. 7th Edition. Philadelphia: Elsevier, 2012. 560p.

2. Ferreira RCS, Riffel A, Santana AEG. HIV: mecanismo de replicação, alvos farmacológicos e inibição por produtos derivados de plantas. Quím. Nova. 2010;33(8):1743-55.

3. Ministério da Saúde. Aids: etiologia, clínica, diagnóstico e tratamento. Brasília: Unidade de Assistência, 2002. Available from: http://bvsms.saude.gov.br/bvs/publicacoes/Aids_etiologia_clinica_ diagnostico_tratamento.pdf
4. Zijenah LS, Katzenstein DA, Nathoo KJ, Rusakaniko S, Tobaiwa O, Gwanzura C, et al. T lymphocytes among HIV-infected and -uninfected infants: $\mathrm{CD} 4 / \mathrm{CD} 8$ ratio as a potential tool in diagnosis of infection in infants under the age of 2 years. J Transl Med. 2005; 3(1):6.

5. National Association of Manufactures. Publications (2016). CD4/ CD8 ratio. [Internet]. London: NAM Publications; 2016 [cited 2016 December 12]. Available from: http://www.aidsmap.com/CD4CD8ratio/page/1733224/

6. Serrano-Villar S, Sainz T, Moreno S. Monitoring the CD4/CD8 ratio: a promising indicator of disease progression in HIV-infected individuals? Future Virol. 2015;10(1):1-4.

7. Arcavi L, Benowitz NL. Cigarette smoking and infection. Arch Intern Med. 2004;164(20):2206-16.

8. Ministério da Saúde. Boletim Epidemiológico Aids e DST 2015. Brasília: MS; 2015. Available from: http://www.aids.gov.br/pt-br/ pub/2015/boletim-epidemiologico-hivaids-2015

9. Guerro AC, Andretta IB, Bello SL, Trevisol DJ, Schuelter-Trevisol F. Causes of hospital admission of AIDS patients in southern Brazil, 2007 to 2012. Rev Soc Bras Med Trop. 2014; 47(5):632-6.

10. Buzon MJ, Martin-Gayo E, Pereyra F, Ouyang Z, Sun H, Li JZ, et al. Long-term antiretroviral treatment initiated at primary HIV1 infection affects the size, composition and decay kinetics of the reservoir of HIV-1 infected CD4 T cells. J Virol. 2014; 88(17):10056-65.

11. Geng EH, Deeks SG. CD4+ T cell recovery with antiretroviral therapy: more than the sum of the parts. Clin Infect Dis. 2009; 48(3):362-4.

12. Samet JH, Cheng DM, Libman H, Nunes DP, Alperen JK, Saitz R. Alcohol consumption and HIV disease progression. J Acquir Immune Defic Syndr. 2007;46(2):194-9.

13. Grabar S, Tattevin P, Selinger-Leneman H, La Blanchardiere A, Truchis P, Rabaud C, et al. Incidence of herpes zoster in HIV-infected adults in the combined antiretroviral therapy era: results from the FHDH-ANRS CO4 cohort. Clin Infect Dis. 2015;60(8):1269-77.

14. Blank LJ, Polydefkis MJ, Moore RD, Gebo KA. Herpes zoster among persons living with HIV in the current antitetroviral era. J Acquir Immune Defic Syndr. 2012;61(2):203-7.

15. Huang TL, Leu HS, Liu JW. Lymphocyte subsets and viral load in male AIDS patients with major depression: naturalistic study. Psychiatry Clin Neurosci. 2006; 60(6):687-92. 